\title{
The Impact of the Belt and Road Initiative on RMB Internationalization and Development Strategies for Mutual Benefit
}

\author{
Yuan Li \\ International Business School \\ Yunnan University of Finance and Economics \\ Kunming,China \\ 879519254@qq.com
}

\begin{abstract}
On the big stage of the world, the Chinese economy has increasingly become an indispensable and important force, making the realistic demand for RMB internationalization deeply rooted in the hearts of the people. The proposal and promotion of the "The Belt and Road" strategy has played a catalytic role, making the RMB develop rapidly in the process of internationalization. "The Belt and Road" strategy is not only for Asia, Europe and Africa, but also for countries around the world. Therefore, it is of great practical significance to thoroughly follow up and understand the implementation of the "One Belt, One Road" strategy and dynamically analyze the impact of the strategy on the internationalization of the RMB in order to promptly propose effective countermeasures. This paper focuses on the content and theoretical research of the "The Belt and Road" strategy, and deeply analyzes the impact of the "The Belt and Road" strategy on the internationalization of the RMB, so as to further explore the countermeasures for mutual benefit and win-win with relevant interest countries.
\end{abstract}

Keywords: "The Belt and Road", RMB internationalization, win-win, countermeasures

\section{INTRODUCTION}

In recent years, on the world stage, the Chinese economy has increasingly become an indispensable and important force, becoming the world's second largest economy after the United States and laying a solid foundation for the internationalization of the RMB. What is worthy of recognition is that the "One Belt, One Road" strategy and the internationalization of the RMB have become an important part of China's foreign strategy, representing China's active exploration of a new model of global governance. Efforts to seek a common point of economic growth have fully demonstrated that China is a responsible big country. The proposal and promotion of the "The Belt and Road" strategy has acted as a catalyst, making the $\mathrm{RMB}$ develop rapidly in the process of internationalization.

In this regard, scholars have conducted extensive and indepth discussions. Lin Lefen and Wang Shaonan (2016) used a quantitative analysis method to compare the internationalization level of currencies along the "The Belt and Road" countries and current major countries. On the one hand, it is pointed out that compared with the internationalization level of traditional international currencies (dollar, pound, yen), the internationalization of the RMB is still in its infancy, and the gap between it and the internationalized currency is very large; on the other hand, with emerging countries (The internationalization level of the Canadian dollar and Australian dollar currency is compared. It is pointed out that the RMB replaced the Canadian dollar and the Australian dollar in November 2014, becoming the fifth largest payment currency in international settlement. Finally, it also compared the major countries of the "The Belt and Road"(Rub).,Singapore dollar,won,etc.)The level of internationalization of the currency indicates that the level of internationalization of the national currency involved in the construction of the "Belt and Road" is generally low. Since 2011, the RMB has become the currency with the highest level of internationalization in the "Belt and Road" region [1]. It can be seen that under the "The Belt and Road" strategy, the development of RMB internationalization has broad prospects, but the internationalization of the RMB must be regarded as a medium- and long-term development strategy of the country. Huang Weiping and Huang Jian (2015) believe that the Belt and Road Initiative strategy has a positive impact on the internationalization of the RMB: First, the construction and improvement of the infrastructure brought about by the "The Belt and Road" will help the RMB to "go out" further; second, the countries along the way will be unimpeded.Trade will deepen the internationalization of the RMB;third,the establishment of a financial platform will ensure a smoother"going out" of the RMB; fourth, strengthening the cultural exchanges will consolidate the status of the RMB in the periphery [2]. Sun Mingwei (2016) elaborated on the negative impact of the Belt and Road Initiative on the internationalization of the RMB. He believes that countries with underdeveloped countries will increase the risk of financial market volatility. At the same time, taking the United States as an example, it is pointed out that the increase in the level of internationalization of the RMB will trigger The Riffin puzzle" [3]. As the supply and demand situation of the RMB is becoming more and more complicated, it has increased the difficulty of regulation and control, which will weaken the independence of China's monetary policy to a certain extent. 
Although extensive research has been carried out on "The Belt and Road" and RMB internationalization at domestic and abroad, many far-reaching conclusions and suggestions have been drawn, but most of the research is based on the consideration of national macroeconomic policies, and more is the station. From the perspective of the Belt and Road, it analyzes its impact on the internationalization of the RMB, and does not propose corresponding countermeasures and suggestions based on the perspective of mutual benefit and win-win. Therefore, this paper selects the national strategy background of "The Belt and Road" and combines the achievements and experience to study the impact of the "The Belt and Road" strategy on the internationalization of the RMB It is hoped that some countermeasures will be obtained for mutually beneficial and shared development of the countries.

\section{THE CURRENT DEVELOPMENT OF THE INTERNATIONALIZATION OF THE RMB}

The internationalization of the RMB means that the internationalization status of the RMB is widely recognized internationally, and the RMB is widely used in the process of pricing, settlement and reserve currency in overseas trade. At present, with the basic development of China's economy, the RMB has been accepted as payment settlement currency by many countries.

In the past three years, the internationalization of the RMB has entered a new stage of development. In October 2016, the RMB was formally included in the International Monetary Fund's Special Drawing Rights (SDR) currency basket, indicating that the internationalization of the RMB has been highly recognized by the International Monetary Fund. According to (SWIFT) statistics, in December of the same year, the RMB has risen to become the sixth largest payment currency in the world, with a market share of $1.68 \%$, and the scope of RMB issuance will continue to expand. According to incomplete statistics, as of the beginning of 2017, more than 60 countries and regions have included RMB in official foreign exchange reserves. At the same time, the RMB is also steadily advancing in the convertibility of capital projects, marking the increasing openness of China's foreign currency. In May 2018, the RMB cross-border payment system (CIPS) was fully operational, covering the major financial markets in the world, further improving the liquidation and settlement efficiency of $\mathrm{RMB}$ cross-border funds, and promoting the use of the RMB on a global scale.

In the process of internationalization, a country's currency needs to go through the development path of "peripheralization-regionalization-globalization". In terms of the degree of internationalization of the RMB, it is still in the transitional period from peripheralization to regionalization. It should be firmly believed that under the favorable trend of China's economy to maintain rapid development and the "The Belt and Road" strategy, the circulation of the RMB will become wider and wider, and the number will become wider and wider, eventually making the internationalization of the $\mathrm{RMB}$ an inevitable trend.

\section{THE IMPACT OF THE “THE BELT AND ROAD” ON THE INTERNATIONALIZATION OF THE RMB}

\section{A. The Positive Impact}

1) Expanding the use of overseas $R M B$ and enhancing China's influence on the world economy

In recent years, China's economic base has been steadily consolidated and rapidly grown into the world's second largest economy. Along with the in-depth promotion of the "The Belt and Road" strategy, China has fully utilized the characteristics of complementing the industrial structure advantages of countries along the route, thereby further expanding the use of the $\mathrm{RMB}$ in the circulation field. In Southeast Asia, for example, these countries have comparative advantages in primary products such as energy, minerals, and agricultural raw materials. China mainly exports manufacturing materials such as building materials, clothing, and steel, as well as infrastructure industries such as electricity and high-speed rail. In such a trade process, since the two sides have a higher degree of international recognition of the RMB, they can directly use the RMB as the settlement currency. On the one hand, it satisfies the needs of all parties and realizes the optimal allocation of resources. On the other hand, the RMB has gradually circulated around, laying a foundation for the internationalization of the RMB. It can be seen that with the help of the "One Belt, One Road" strategy, the traditional form of payment with the US dollar as the settlement currency has been broken, and more and more countries are willing to use and hold the RMB.

2) Conducive to the gradual opening up of the entire financial sector in China and the realization of the $R M B$ "going out"

Since the "The Belt and Road" initiative has been launched for five years, it has stimulated a large number of emerging financial needs, creating historic development opportunities for banks and various financial institutions in countries along the route. The 2018 government work report also mentioned that the market for bank card clearing and other markets was opened in an orderly manner, and the restrictions on the business scope of foreign-invested insurance brokers were liberalized, and the market access standards for Chinese and foreign banks were unified. It is expected that the scope of opening up the financial sector will become larger and larger. In the past five years, the launch of "Shanghai-Hong Kong Stock Connect", "Shenzhen-Hong Kong Stock Connect" and "bond-to-bond" have meant that China has made cautious and appropriate measures for RMB convertibility. With the deepening of economic and trade exchanges between countries along the route, commercial banks along the line have carried out a lot of cooperation in the fields of asset trading, project financing, settlement and liquidation, etc. according to the new business rules. In May 2017, the "The Belt and Road" interbank normalization cooperation member unit has expanded to 53 and has recommended more than US\$2.5 billion through financial platforms. In October of the same year, in order to reduce the risk of foreign exchange transactions, the RMB foreign exchange market in China began to operate the RMB foreign currency synchronous settlement mechanism, which greatly improved the efficiency of business operations. All 
these signs indicate that the "The Belt and Road" strategy will promote the offshore payment settlement of the RMB, which is conducive to the gradual opening up of the entire financial industry in China.

3) Realize the overseas financing of $R M B$ as the denominated currency and broaden the direct financing channels

Relying on the proposal of key cooperation projects in the "The Belt and Road" strategy - China Finance and the countries along the line are actively building financing platforms, promoting the opening and development of the Asian bond market, and establishing an international investment and financing system to achieve mutual Overseas financing for major currency denominations solved the funding gap and increased financing channels. For example, China, as a major funder, plays an important role in the preparation and operation of financial institutions such as the AIIB, the BRICS Development Bank, and the Silk Road Fund. Therefore, these financial platforms can be used to develop backward economics along the line. The state issued RMB loans to meet its financing needs for infrastructure construction and other production areas. At the same time, China also dispersed the pressure on the balance of payments surplus and obtained part of the investment income. According to the "One Belt, One Road" Trade and Investment Forum, as of April 2018, the Chinese banking industry has awarded nearly 400 billion U.S. dollars to countries and regions along the "The Belt and Road", and has issued more than 200 billion U.S. dollars in loans, which has contributed to the "The Belt and Road". Nearly 2,700 construction projects and 210,000 jobs were created. With the help of the "The Belt and Road", more and more countries along the line can obtain financial loans from financial institutions such as the AIIB, and realize overseas financing with $\mathrm{RMB}$ as the denominated currency, thus broadening the direct financing channels.

\section{B. The Adverse Impact}

1) The improvement of the internationalization level of the $R M B$ will increase the difficulty of macroeconomic regulation and control.

"The Belt and Road" strategy promoted the international use of the RMB and raised the international level of the RMB, but it also increased the difficulty of macroeconomic regulation and control of the domestic monetary policy. At present, China's central bank can effectively use the three major monetary policy tools of the statutory reserve ratio, open market business and discount policy to achieve effective control and adjustment of the supply and credit of the RMB. When the "The Belt and Road" strategy accelerates the internationalization of the RMB, the supply and demand of the $\mathrm{RMB}$ is affected by both domestic demand and international demand. The central bank needs to consider more factors in the regulation of domestic monetary policy, and the situation is more complicated and more difficult. Because of the international demand for $\mathrm{RMB}$, foreign exchange transactions, whether for profit, value preservation or risk aversion, will affect the implementation of domestic macro policies. In addition, from the perspective of a responsible big country, China must take into account the chain reaction to the economies of countries and regions along the line when formulating monetary policy, which also increases the difficulty of implementing monetary policy and may make our current currency The way the policy is regulated is facing change.

2) The expansion of the money market will intensify financial market volatility, which is not conducive to the internationalization of the RMB

"The Belt and Road" strategy has promoted bilateral currency cooperation among countries along the line through the financing of financial projects, and expanded the RMB currency market while also increasing the factors of instability in the domestic financial market. Compared with the larger emerging economies such as China, India, South Korea and Singapore, most of the countries along the "The Belt and Road" are economically underdeveloped countries. Their currency currency risk is relatively high, and financial institutions are able to withstand risks. It is weak, so it is easy to generate currency credit and financial risks. Through the "The Belt and Road" strategy of China Unicom and the exchange rate transmission effect, the potential credit default risk along the countries and regions along the line is difficult to pass to the AIIB to China, triggering China's financial market.

3) The continuous expansion of the RMB's overseas circulation is likely to trigger "Triffin's Paradox"

"The Belt and Road" strategy promotes the circulation of $\mathrm{RMB}$ in neighboring countries and regions, in the process of becoming international, the RMB may also encounter the "Triffin Paradox" faced by the US dollar [4]. In the US dollar, the US dollar is the world currency. The growth of the global economy requires a large number of US dollars to maintain a stable international supply. This is achieved through the US balance of payments deficit, but the core of the international currency is the stability and firmness of the currency. In turn, the US balance of payments is required to have a long-term surplus.Therefore, these two goals are contradictory and cannot be realized at the same time. Similarly, as the "The Belt and Road" strategy promotes the increase in the volume of trade around, more and more countries along the route are considering the inclusion of RMB in official foreign exchange reserves for actual settlement and payment. This will undoubtedly lead to the continuous flow of RMB from China and a large amount of precipitation in offshore financial markets outside China.When it reaches a certain level, it will inevitably lead to China's balance of payments deficit, and the long-term deficit will bring about the depreciation of the RMB, causing the problem of "insufficient confidence" of the countries and people holding RMB financial assets, thus making the RMB face a trade deficit and not conducive to the internationalization of the RMB.

\section{THE COUNTERMEASURES FOR THE PURPOSE OF MUTUAL BENEFIT AND WIN-WIN}

\section{A. Continue to strengthen financial cooperation between China and countries along the Belt and Road Initiative}

Since Capital Finance is an important cooperation project under the "The Belt and Road" strategy, it should fully grasp 
this policy advantage and continue to expand the depth of financial cooperation between China and countries along the line. On the one hand, we should gradually promote the reform of the financial market, prudently and steadily expand the opening up of the financial industry, and create a favorable environment for the internationalization of the RMB. On the other hand, deepen the cooperation between China and the national banks along the "The Belt and Road", accelerate the construction of the RMB settlement network, and promote multilateral financial cooperation through syndicated loans and credits. In addition, we will build an offshore financial center for the RMB facing neighboring countries. For this reason, we can consider further deepening financial cooperation with neighboring countries, which will not only optimize the supply structure of the "The Belt and Road" financial services, integrate financial resources, but also provide financial services to countries along the route. The field has brought new growth momentum, achieved mutual benefit and win-win in the financial sector, and finally laid a solid foundation for promoting the internationalization of the RMB.

\section{B. Further promoting the use of RMB in countries and regions along the "The Belt and Road"}

Under the "The Belt and Road" strategy, the internationalization of the RMB will be steadily advanced, and the circulation of $\mathrm{RMB}$ in countries along the border and surrounding areas should continue to be further promoted. First, efforts should be made to create a domestic environment in which the RMB is internationally developed, strengthen exchanges with high-level governments along the line, eliminate the adverse effects of geopolitics on China, and create more opportunities for economic and trade cooperation between the two sides. Second, reduce the limiting factors of RMB cross-border transactions. For example, cancel the policy restrictions on $\mathrm{RMB}$ entry and exit in border areas, speed up the establishment of RMB convertibility test sites, and implement RMB specialization management policies in areas along the border (such as Yunnan and Guangxi border areas). Finally, the government should encourage Chinese enterprises and institutions to Proactive use of RMB in foreign economic and trade exchanges, providing preferential trade policy support, such as tax reductions or price concessions.

\section{Improving the risk aversion measures of the RMB in the process of internationalization}

As most of the countries along the "The Belt and Road" are among the economically backward developing countries, the economic development is unbalanced, the political environment is unstable, and religious beliefs and legal sources are different. Some uncertain risk factors are easy to pass the "The Belt and Road". The link is passed to countries. Therefore in the process of RMB internationalization, improving the risk prevention mechanism between China and countries along the line is a protective barrier to dual multilateral cooperation. In terms of cooperation, countries along the route should follow the "The Belt and Road" construction and adhere to the principles of mutual cooperation, sharing, and co-construction, adhere to mutual benefit and win-win, and avoid political conflicts, economic conflicts, and ethnic conflicts. In terms of financial innovation, countries along the line must strengthen the supervision of financial instruments and products. In terms of market supervision, in the face of foreign financial institutions to enter or conduct business, the government should strictly follow the relevant regulations to conduct prudential supervision and improve the supporting supervision mechanism.

\section{REFERENCES}

[1] Lin Lefen, Wang Shaonan,"Construction of the Belt and Road Initiative and the Internationalization of the RMB,"International Political Economy, 2015(15)

[2] Huang Weiping, Huang Jian,"How the RMB goes out under the Belt and Road Initiative," Academic Frontiers, 2015 (3).

[3] Sun Mingwei,"The Impact of the Belt and Road Initiative on the Internationalization of the RMB and Its Countermeasures,"Economic Research Guide, 2016(17).

[4] Guo Jianguo, Han Linlin," Analysis of the Impact of "One Belt, One Road” on RMB Internationalization,” Heilongjiang Finance, 2016(1).

[5] Han Yaguang,"Thoughts on the Internationalization of RMB under the Background of the Belt and Road Initiative,"Reform and Strategy, 2015(8).

[6] Yang Guangqing, Du Haipeng,"The Impact of RMB Exchange Rate Changes on China's Export Trade," Economist, 2015(11).

[7] Weidong, Liu,D. Michael,and G.Boyang,"A discursive construction of the Belt and Road Initiative: From neo-liberal to inclusive globalization."Journal of Geographical Sciences,2018,pp.1199-1214.

[8] Fan,Zhang,et,al."The Effect of RMB Internationalization on Belt and Road Initiative: Evidence from Bilateral Swap Agreements." Emerging Markets Finance \& Trade,2017.

[9] Mcnally, Christopher A."The political economic logic of RMB internationalization:A study in Sino-capitalism."International Politics,2015,pp.704-723. 